\title{
HOMO CULTURALIS VERSUS CULTURA ANIMI
}

\author{
PATRIK MATURKANIČ
}

College of Applied Psychology

Akademická 409, 41155 Terezín, Czech Republic

E-mail address: maturkanic@vsaps.cz

ORCID: https://orcid.org/0000-0002-1087-3847

IVANA TOMANOVÂ ČERGEŤOVÂ

College of Applied Psychology

Akademická 409, 41155 Terezín, Czech Republic

E-mail address: cergetova.ivana@gmail.com

ORCID: https://orcid.org/0000-0001-7750-0634

\section{PETER KONDRLA}

Department of Religious Studies, Faculty of Arts

Constantine the Philosopher University in Nitra

Hodžova 1, 94974 Nitra, Slovak Republic

E-mail address: pkondrla@ukf.sk

ORCID: https://orcid.org/0000-0003-4857-5578

\section{VIKTORIA KURILENKO}

Russian Language Department Medical Institute Peoples' Friendship University of Russia (RUDN University)

Miklukho-Maklaya 6, 117198 Moscow, Russia

E-mail address: vbkurilenko@gmail.com

ORCID: https://orcid.org/0000-0003-3638-9954

\section{JOSÉ GARCIA MARTÍN}

University of Granada, Department of Sociology

Faculty of Political Sciences and Sociology

Calle Rector López Argüeta s/n, 18001 Granada, Spain

E-mail address: jgarciamartin@ugr.es

ORCID: https://orcid.org/0000-0001-7401-0613 


\section{ABSTRACT}

Aim. Presented study deals with the cultural dimension. It analyses external and internal human activities, that are creating the polarity develop values. The aim of the study is to clarify and connect the theoretical level of thinking with the reality of life practice, which shows the true meaning of human existence.

Concept. The study highlights the importance of human thinking and decision making. Through the actions, one develops and creates the values of human dignity. The study focuses on the importance of two dimensions (horizontal and vertical dimensions of man), the relationship of man to God. Human culture includes behaviour that can be learned and is shaped by the environment in which one lives. This contribution is to clarify a culture of thinking that is a reflection of the soul of human being. Since culture is not only a matter of individual dispositions but also of social reality, it is right to underline this dual aspect of the plurality dimension (Binetti et al., 2021).

Conclusion. The study identifies a fundamental aspect of the culture's values, which show the potential of the soul of every human being. Human values influence thinking and actions of human being, thus creating the image of God.

Key words: culture, man, thinking, Universum, soul, death, brotherhood, love

\section{INTRODUCTION}

$\mathrm{H}$ uman being is distinguished by a wide range of internal and external activities. These activities are based on his or her interest in creating new things or cultivating them, developing values. Thus, we can deduce that these will be the matters that human is not born with but will cultivate them in the usual way (lat. collere - culura), or, as the previous sentence implies, that are acquired from a previous generation. In this way, a human declares that s/he is indeed Homoculturalis, a person capable not only of caring for the worries of "everyday bread," but also of a style worthy of a man considering the interest in spiritual values and, as stated in Hedviga Tkáčová, Martina Pavlíková, Miroslav Tvrdoň, and Zita Jenisová's (2021) work, duly responsible for them as well as for the world and its sustainability. According to the Greek philosopher Plato, living in the $5^{\text {th }}$ century BC, it is the caring of the soul (lat. Culturaanimi), i.e. everything that benefits the harmonisation structure of our internal self-realisation. Therefore, it is important not only to speak openly about these things, but to encourage the public to take a deeper self-reflection, and thus not to be afraid to discover things that will help us to be not only a specific personality in the context of human society but also an asset to others. The tension between rationality and emotionality of these processes indicates the key position of moral formation agent and thence the urgent need for deep, intimate and safe interpersonal relationships (Králik \& Máhrik, 2019a): one should not be afraid to use the term "search" in connection with this presented topic. This points to a space of "unlimited" movement, where the human motive, but above all the desire to fulfil human existence offering the meaningfulness of humanities goals, points to a colourful possibility of descending into a web, which is also written about by the well-known American anthropologist Clifford Geertz (1926-2006): 
Man is an animal suspended in webs of significance he himself has spun, with culture consisting of those webs in which the analysis is "not an experimental science in search of law but an interpretative one in search of meaning." (Geertz, 1973, p. 5)

In the symbolism of the search, we also see a certain essence of the social character of people, but also a challenge that can help us to "reveal" cultural reality not only in ourselves but also in a group of people claiming to belong to one social entity. In this layered system, in the words of Geertz, we discover multiple webs of human stories of one common network called civilisation structure with its original uniqueness.

\section{METHODOLOGY}

The present study analyses external and internal human activities. The aim of the study is to clarify and connect the theoretical level of thinking with the reality of life practice, which shows the true meaning of human existence with the accent on developing and creating the values of human dignity and the culture of thinking.

This study mainly ponders the importance of two dimensions (horizontal and vertical dimensions) of human in the relationship with God. In this methodological framework, authors try to identify a fundamental aspect of the culture's values, reminding that human values influence the thinking and actions of human beings, and thus they are creating the image of God.

\section{CULTURE OF THINKING}

One of the fundamental elementary factors of a human is the ability to think. Human is a thinking creature and as such is capable of conscious psychic activities through which s/he can create thoughts and work with them:

1) Ideas, which arise based on sensory perception (visual, auditory, motor and other).

2) Concepts, which exist in the consciousness of a human through a certain verbal definition; concepts can be applied to operate and create abstract structures. Thus, we can think of things that cannot be even perceived sensually. This ability troubles our thinking because we are never sure whether what we have been thinking about was not just an illusion or fantasy.

3) United ideas that are discourse-like, which carry the ability of a person to examine the reflection of their thinking, to reveal their logical structure, i.e., the system of relationships between ideas, to set off these relationships, to come to the right conclusions - the logic of correct thinking (Dolista \& Feber, 2007).

On these foundations, human being takes place over the animal world, so that, in the virtue of its humanity and the discretion of its thought processes, 
it participates in the general good of mankind in the best possible way. If we want to grasp the topic presented well, it is appropriate that we first open up one life, and yet two different worlds of men and women. It is clear from biological scientific knowledge that this diversity lies primarily in the genetic field, but also in secondary sectors, such as an equally important element of the environment, which contributes to a large extent to the behaviour of the male and female populations. This brings us to a European person, where we want to determine with honest self-reflection the specifics of their thinking, which naturally interferes with the culture of their behaviour. Unlike the world of women, the male world is more systematic, usually understanding technical connections, and it cannot empathise with the feelings of others, similarly to the empathic sphere of the opposite sex. In communication and relationship terms, men are predominantly competitive, as opposed to the female way of thinking, where cooperative, more tolerant, i.e. positive decision-making, prevails.

If we explore the very meaning of the phrase "culture of thought," we come to the conclusion that this is not a space of strictly ordered instance, whether of a secular or religious character, but a completely free act worthy of a human being (cf. Ambrozy et al., 2018; Pavlíková, 2016; Tkáčová et al., 2021; Zalec \& Pavlíková, 2019). Through gradual socialisation, a human acquires the attributes of his/her own culture and learns to be a successful member in it: gets acquainted with the admissible operandi mode, accordingly inadmissible for the social group of which s/he is a member (Tkáčová, Pavlíková, Tvrdoň, \& Prokopyev, 2021). Thus, the individual culture of thought means that there is no instance that can hold anyone accountable when a person himself or herself, at his/her discretion, decides on something and is willing to bear the consequences of his/her actions.

\section{THE UNIVERSUM OF HUMAN CULTURE OR HOW DID IT ALL BEGIN AND WHERE IS IT GOING?}

Current culture is not a cultural monument. On the contrary, it is a constantly changing, dynamic and powerful entity in society and the main co-creator of a digital (i.e., online) reality and social reality (Tkáčová, 2021), where people are looking for answers as to what heritage as well as what values they should arise and intensively develop in the new global-pluralistic culture. Moreover, people face a new world culture where are foreign values and mentalities, unknown traditions and religions, and they "do not know how to perceive and evaluate them; whether to understand and welcome them as guests or to condemn them forever as intruders" (Tkáčová, Al-Absiová, Al-Absi, \& Pavlíková, 2021, p. 166). Real culture, i.e. its objective framework, does not end in the position of "traditional" yesterday and today but is based on the fact of future enduring of spiritual values. Culture, in its true meaning, is not superficial to me, nor a cultural monument or museum. It is something truly sacred. It is not 
only reminiscent of the external and earthly form of the ancestors but also a continuation of the efforts they have made. It is a living, eternal memory that will not die in those who engage in these efforts, because their culmination is precisely those efforts that have been passed down from ancestors to their descendants. Not even a letter that has been newly written on the board of the human spirit will disappear. In this sense, culture is not only magnificent but also a stimulant of the spirit (Ivanov, 1976).

The issue of the essence of thinking, regardless of whether it is research in Europe or on another continent, leads to the fact that, in addition to interpretive frameworks, it is also necessary to consider the cultural, religious but especially social background. We face such a complexity of reality that it is not possible to examine one without the other, especially if we focus our research on the moral dimension of human and ethical thinking within various social entities.

Current ethical calls originating in the advanced technology environment and AI development refer to the need to embrace and convey panoramic reality perception within the current technological, cultural and social contexts. It refers to the required presence of critical thinking and processing of the observed phenomena in terms of assigned tasks in the horizontal plane as well as to the ability to perceive these phenomena organically in the verticality or meta-ethics and metaphysics (Králik \& Máhrik, 2019b, p. 8902).

In the long period of the Tertiary and Quaternary (Cenozoic), we discover a person not only capable of vertically holding the body, but also wisely considering and creating values with full awareness of life in the present. But if we were looking for the most basic point, i.e. the ontological leap, when a person truly became a human being of another kind of primate, we would come to his/her ability to distinguish what is ethical or unethical behaviour. In this sequence of discovery, we see not only the body obtained from not yet fully human breeders, but also its deep self (soul) capable of making free choices and, under different circumstances, choosing between good and evil (Maturkanič, 2020).

It follows from this knowledge that it is in this beginning, i.e. the recognition of good and evil, that one can create a culture of thought worthy of human dignity. And what role does the Universum play in this? It is precisely in the fact that now an important human breakthrough, as explained by the term ontological leap, the Universal of Life, the donation or imprinting of the breath of human life occurs (i.e. soul). Thus, we note that the soul did not develop in the evolutionary way thatcharacterises the transformation of the human box, but by the fact that it was literally given to man. There is a quite simple logical way of explanation that clearly points to a view of a unique, ever-changing, human being: the body shell from the moment of conception to the moment of death. It declares how the human body is, in the context of evolutionary theory, variable and therefore unstable. This indiscoverable fact cannot be refuted compared to the human soul, whose primary moment of beginning we 
define by the origin, i.e. the conception of a person's life in the womb. We come to the assertion that this most fundamental, inner human element is intangible, i.e. invisible, and immutable regarding the different stages of human life.

There is another fundamental question that brings us to the final moment of human existence. What occurs now of a person's death is meant in relation to one's soul, which is intangible, unfolded, without quantity, and thus without any particles to be composed of. In other words, can it not disappear, because only what is composed of particles, or that is internally dependent on something that is composed of particles, can disappear? Logically speaking, there will be a certain separation of the soul from the already inanimate organism (body), while the soul will not, of course, remain "hanging" in the blue-and-white clouds of passive peace, as we sometimes comfort ourselves in a nostalgic way at the sight of our survivors (cf. Pavlíková \& Zalec, 2019). The fact of things is in another dimension that cannot be explained solely by metaphysical reasoning. Yet we do not want to underestimate this search for ourselves, or even let these completely open reflections go unnoticed. In the subtext of a sacred secret concerning the most precious, that is, our spiritual self, it is appropriate to admit that although human is a being of unique possibilities, on the other hand, one cannot see even a certain limitation of his or her knowledge. We are offered a reflection on the variability of life and death, when the early Christian philosopher Augustin of Hipp, seeks the eventuality of possible exits, which culminates in the last sentence of his positive vision:

For no sooner do we begin to live in this dying body, than we begin to move ceaselessly towards death. For in the whole course of this life (if life we must call it) its mutability tends towards death. Certainly there is no one who is not nearer it this year than last year, and tomorrow than today, and today than yesterday, and a short while hence than now, and now than a short while ago. For whatever time we live is deducted from our whole term of life, and that which remains is daily becoming less and less; so that our whole life is nothing but a race towards death, in which no one is allowed to stand still for a little space, or to go somewhat more slowly, but all are driven forwards with an impartial movement, and with equal rapidity. For he whose life is short spends a day no more swiftly than he whose life is longer. (Augustin, https:/ /www. logoslibrary.org/augustine/city/1310.html).

\section{CONCLUSION}

The present study analyses external and internal human activitiesandhighlights the importance of human thinking and decision making. The starting point is the belief that human culture includes behaviours that can be learned, thus this contribution is to clarify a culture of thinking that is a reflection of the soul of a human being. Similarly, human culture is a matter of social reality. We have discussed herein the dual aspect of the plurality dimension (Binetti et al., 2021). 
We came to an open, not limited conclusion when we pointed to a culture of thought that is linked to the culture of the soul. It does not wither, but it is permanently nourished in the dynamics of its Originator, which we called the Universal of Lifein the paper. The "white father" speaks aptly of this when, in his latest encyclical Fratellitutti, explains the basis on which the universality of Majestatis rests, which invites us to follow it:

Love also impels us towards universal communion. No one can mature or find fulfilment by withdrawing from others. By its very nature, love calls for growth in openness and the ability to accept others as part of a continuing adventure that makes every periphery converge in a greater sense of mutual belonging. As Jesus told us: "You are all brothers" (Mt 23:8). This need to transcend our own limitations also applies to different regions and countries. Indeed, the ever-increasing number of interconnections and communications in today's world makes us powerfully aware of the unity and common destiny of the nations. In the dynamics of history, and in the diversity of ethnic groups, societies and cultures, we see the seeds of a vocation to form a community composed of brothers and sisters who accept and care for one another. (Francis, January 10, 2021).

\section{ACKNOWLEDGEMENT}

This article was published with the support of International Scientific Research Project: Pastoral practice, psychology and philosophical-theological-social fragments in the light of the $21^{\text {st }}$ century (contract number: 010-2021). Cooperation among: Sociedad Hispánica de Amigos de Kierkegaard, University of Granada (Spain) and College of Applied Psychology in Terezín (Czech Republic), 2021-2022.

\section{REFERENCES}

[1] Ambrozy, M., Králik, R., \& Poyner, J. (2018). The issue of periodisation in Wittgenstein's philosophy of religion. European Journal of Science and Theology, 14(1), 115-124.

[2] Augustine Saint. (354-430). City of God. Book XIII. https://www.logoslibrary.org/augustine/ city/1310.html.

[5] Binetti, M. J., Králik, R., Tkáčová, H., \& Roubalová, M. (2021). Same and other: From Plato to Kierkegaard. A reading of metaphysical thesis in an existential key. Journal of Education Culture and Society, 12(1), 15-31. https://www.doi.org/10.15503/jecs2021.1.15.31.

[4] Dolista, J., \& Feber, J. (2007). Filosofická antropologie [Philosophical anthropology]. České Budějovice: VŠERS.

[5] Francis (2020). Encyclical Letter Fratelli Tutti, 95-96. Retrieved January 10, 2021, from http:// www.vatican.va/content/francesco/en/encyclicals/documents/papa-francesco_20201003_ enciclica-fratelli-tutti.html.

[6] Geertz, C. (1973). The interpretation of cultures. New York: Basic Books.

[7] Ivanov, V. I. (1976) Corrispondenza da un angolo all'altro [Correspondence from corner to corner]. Milano: La Casa di Matriona.

[8] Khonamri, F., Králik, R., Vítečková, M., \& Petrikovičová, L. (2021). Self-assessment and EFL literature students' oral reproduction of short stories. European Journal of Contemporary Education, 10(1), 77-88. https://www.doi.org/10.13187/ ejced.2021.1.77. 
[9] Králik, R., \& Máhrik, T. (2019a). Interpersonal relationships as the basis of student moral formation. ICERI 2019. Proceedings of the 12th International Conference of Education, Research and Innovation. Seville: ICERI, 8896-8900.

[10] Králik, R., \& Máhrik, T. (2019b). Metaphysics as a base for improving critical thinking. ICERI 2019. Proceedings of the 12th International Conference of Education, Research and Innovation. Seville: ICERI, 8901-8903.

[11] Maturkanič, P. (2020). Základy etiky 2 [Fundamentals of ethics 2]. Terezín: VŠAPs.

[12] Pavlíková, M. (2016). Concept of anxiety and its reflection in Auden's work "The age of anxiety". European Journal of Science and Theology, 12(4), 111-119.

[13] Pavlíková, M., \& Zalec, B. (2019). Struggle for the human self and authenticity: Kierkegaard's critique of the public, established order, media, and false Christianity. Bogoslovni vestnik/Theological Quarterly, 79(4), 1015-1026.

[14] Tkáčová, H., Al-Absiová, E., Al-Absi, M., \& Pavlíková, M. (2021). “Media invasion” against Islam in the context of the Slovak Republic. Media Literacy and Academic Research, 4(1), 165-179.

[15] Tkáčová, H., Pavlíková, M., Tvrdoň, M., \& Jenisová, Z. (2021). The use of media in the field of individual responsibility for sustainable development in schools: A proposal for an approach to learning about sustainable development. Sustainability, 13(8), 4138. https:/ /www.doi. org/10.3390/su13084138

[16] Tkáčová, H., Pavlíková, M., Tvrdoň, M., \& Prokopyev, A. I. (2021). Existence and prevention of social exclusion of religious university students due to stereotyping. Bogoslovni vestnik/Theological Quarterly, 81(1), 199-223. https:/ / www.doi.org/10.34291/BV2021/01/Tkacova.

[17] Tkáčová, H. (2021). Initiatives against disinformations on the Internet in the first year with Covid 19 in Slovakia. QUAERE 2021. Proceedings of the 9th Interdisciplinary Scientific Conference for PhD students and assistants, 714-722.

[18] Zalec, B., \& Pavlíková, M. (2019). Religious tolerance and intolerance. European Journal of Science and Theology, 15(5), 39-48. 